\title{
Macroeconomics and Development of Seaport. Case of Vietnam
}

Thi Hong Van Pham, Thi Mai Thom Do

Vietnam Maritime University, vanpth@vimaru.edu.vn

Abstract

Seaport industry plays an important role in local and national economic development. The development of the seaport industry creates a competitive advantage, promotes international trade and speeds up the integration process of nations, especially in developing countries. Many studies have noted the importance of seaports to economic development. Economic development is also one of the crucial factors in seaport development. Economic growth will promote domestic production and improve investment efficiency. The development of import and export activities directly affects the supply of goods and the scale of operations of seaports; the increasing in industrial-agricultural output will increase the volume of goods, thereby promoting the seaport industry. This research analyses the relationship between economic growth, export-import operations, industry \& agriculture to cargo through ports based on statistical data for the period 2000-2019. This study selects the case of Vietnam, a developing economy with a long coastline along with the country, and its shipping capacity ranked 4th in the ASEAN region.

Keywords: seaport industry; cargo through ports; GDP; import-export; industry and agriculture

JEL Classification: L9

(c) Thi Hong Van Pham, Thi Mai Thom Do, 2020

\section{Introduction}

The role of seaports in local and national economic development has been confirmed in numerous studies (Bayar Caglak et al., 2011; Boonadir et al., 2012; Dwarakish \& Salim, 2015; Park \& Seo, 2016; Jouili, 2016). Not only contributing directly to economic growth, but the development of the seaport industry also promotes international trade and economic integration of nations (Dwarakish \& Salim, 2015). The development of the seaport industry also creates jobs, reduces production and transportation costs, promotes domestic production to the world market as well as creates goods distribution centres among economic sectors (Park \& Seo, 2016). In 2012, the seaport industry contributed directly 56 million euros to GDP in European countries, and the total contribution to GDP, including the indirect portion was up to 145 billion euros (Goodwin, 2016). In the UK, the seaport industry contributed 21.2 billion GBP to the economy, 6.2 billion GBP to income taxes in 2011 and created 391,800 jobs (Oxford Economics, 2013).
For developing countries, the seaport industry plays a very crucial role in several countries having coastal advantages. Specifically, 95 per cent of total cargo trade between Tunisia and the rest of the world was made by maritime roads in the period 1983-2011 (Jouili \& Allouche, 2016). Chowdhury and Erdenebileg (2006) show that landlocked countries which own no seaports may face significant cost disadvantages due to higher transportation costs. They even have to pay the costs related to policies, politics such as tax imposed on goods passing international borders. The study also indicates that landlocked regions would encounter a lower level of GDP compared to port regions. The difference in GDP could be as large as approximately 40 per cent in the case of developing countries.

Seaport development becomes an essential aspect of many countries' economic development strategy, and this is also a topic that attracts many researchers. Many studies have analysed the role of seaports and the impact of infrastructure no seaports development. 
However, the analysis of factors affecting seaport development is still limited, especially as concerns macroeconomics factors in the case of developing countries. Seaports contribute and promote economic development, industrial development, international trade growth, and foreign investment. There are also important macroeconomic factors in promoting seaport development. With these factors, policies and economic development strategies have essential impacts on the development of seaport enterprises. Recognising this gap, in this research, the authors focused on analysing the influence of macroeconomic factors on the development of seaport enterprises. The study will use the case of Vietnam, a developing country which has an important geographic location in international trade in the Asia Pacific region. The total volume of goods through Vietnam's seaports achieved 524.7 million tons and 17.8 million TEUs in 2018 (Vietnam Maritime Administration Statistics, 2019).

\section{Literature Review}

How to promote the development of seaport enterprises is one of the questions that many countries and researchers are interested in. Indeed, the macroeconomic environment has impacts on seaport development. Macroeconomic factors will build an appropriate environment to develop seaport enterprises $(\mathrm{Tu}-$ kan et al., 2015). This paper will address the impact of GDP growth, FDI, industry, importexport on the development of seaport enterprises.

Seaport firms contribute significantly to local and national GDP growth (Jiang, 2010; Chang et al., 2014; Bottasso et al., 2014; Jouili \& Allouche, 2014; Dwaralish \& Salim, 2015). On the other hand, economic growth also influences the seaport industry. Economic growth means domestic production and investment also increase. The rise in output leads to higher demand for transport and trade of goods, that is the basis for the development of seaport activities. Likewise, economic growth will raise the government's revenue from income tax and corporate tax. As a result, the government will expand public investment in infrastructure, which is also a factor that promotes the development of seaports. The positive impact of the development of infrastructure on seaport's development is mentioned in the study of Baird (1998) and Jouili (2016). Tukan et al. (2015) show that local economic development will affect the rate of seaport development. Specifically, GDP growth will boost the volume of cargo handling at ports and the likelihood fleet and dock length. Economic growth also supports the efficiency of the transport system. This research also indicates a positive relationship between economic growth and seaport development. Recognising the importance of the seaport industry, governments implement policies and strategies for economic growth, thereby contributing to the development of seaport enterprises.

Besides, import and export activities affect the development of seaports by directly affecting the volume of goods through ports (Jouili, 2016). Sea transport is one of the most economical and cost-effective means of transportation, which is the main transportation channel used by major countries in their import and export activities. Thus, the rapid growth of import and export will directly affect the volume of goods through ports, thereby increasing revenue and creating favourable conditions for seaport development.

Thirdly, seaport development also depends on the level of the national industry. The development of the national industry will increase the volume of goods, thus leading to the development of international trade, thereby increasing the activities of seaport service. The study of Nguyen and Nguyen (2018) also shows that industrial value affects the volume of goods passing through ports and has an impact on seaport revenue. In contrast, the study by Norcliffe (1981) also shows the effect of seaports on the development of industrial zones; in fact, many industries depend on seaports. The development of seaports creates competitive advantages for industrial zones in saving transportation costs, facilitating trade from the supply of goods to suppliers as well as to consumers; attracts local manufacturers and distributors to take advantage of cost and geographical distance. Many governments have built industrial parks near seaports to attract foreign investment (Park \& Seo, 2016). Besides, Jung (2011) examined the contribution of seaports to Korea's economy 


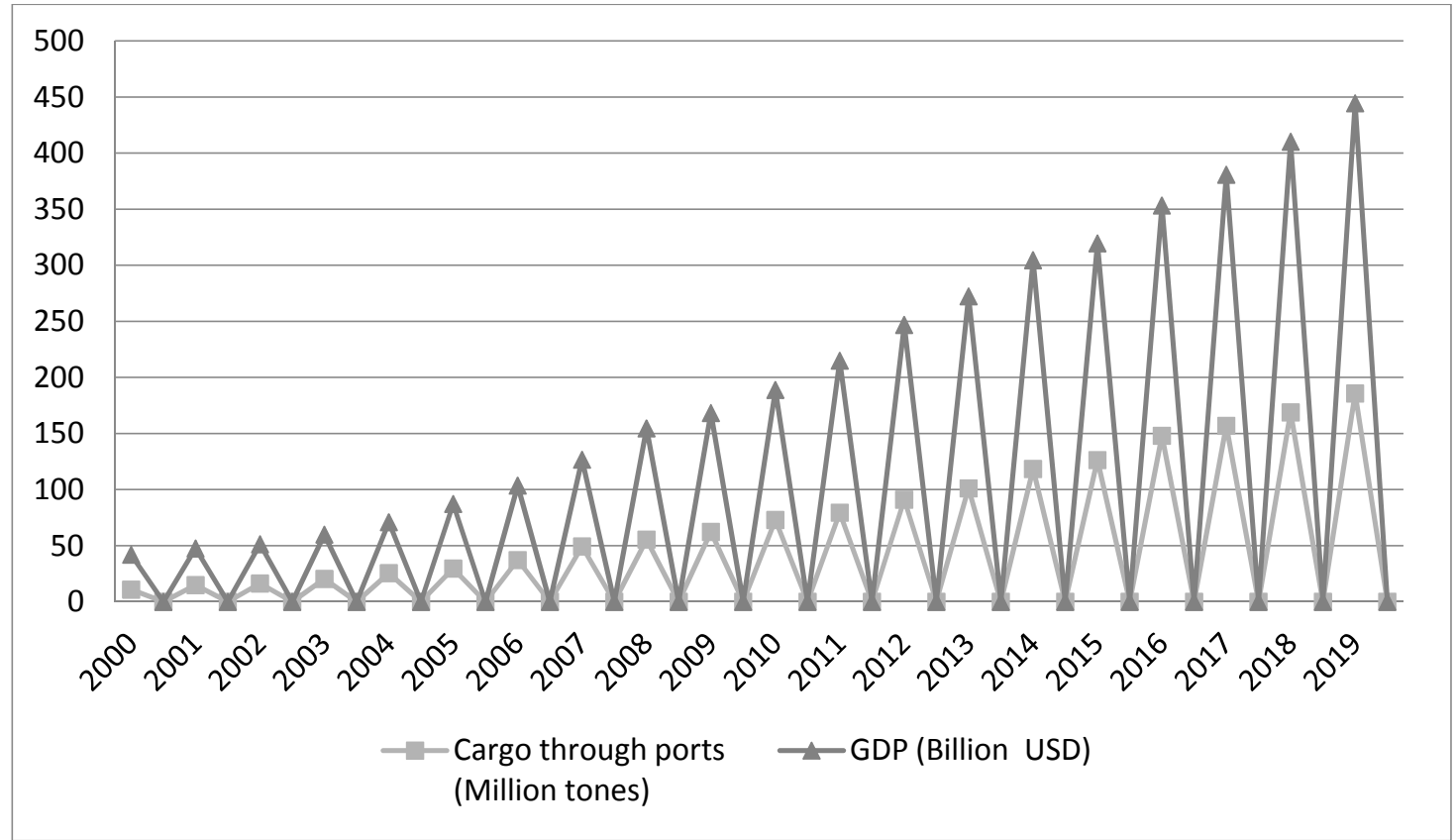

Fig. 1. Cargo through seaports and GDP value of Vietnam in the period 2000-2019

Source: Vietnam General Statistics Office and the Vietnam Maritime Administration, 2019.

and concluded that seaports play a vital role in the development of heavy industries such as steel, shipbuilding and petrochemical industry.

Along with the national industrial development, the development of agriculture and fishing also affects the development of seaport by increasing the volume of goods through seaports (Nguyen \& Nguyen, 2018). It is evident in countries exporting agriculture and seafood processing products such as Thailand and Vietnam. According to statistics of the Ministry of Agriculture and Rural Development of Vietnam, Vietnam's agricultural, forestry and fishery export turnover in 2019 reached the US $\$ 41.3$ billion, accounting for about 27 per cent of the total export turnover. Likewise, the growth of agriculture, fishery and forestry contributes to the increase in cargo and the development of seaport services.

The above analysis denotes that economic growth, export-import, industrial and agricultural development have a positive impact on the volume of goods through seaports. This impact will be considered in the context of Vietnam, a developing economy, in which seaport activity plays an important role in the economy.

\section{Case Study of Vietnam}

Vietnam has a developing economy in which the seaport industry plays an important role.
With a strategic geographic location, Vietnam Sea in the Pacific Ocean occupies one of the busiest international maritime trade routes in the world, connecting the Indian Ocean and the Pacific Ocean. Vietnam's shipping capacity currently ranks 4 th in ASEAN and 30th in the world with more than 1,500 ships of all kinds. Vietnam logistics service is presently ranked 64/160 in terms of development level and ranked 4 th in ASEAN (Report Buyer, 2019). Vietnam has currently signed trade agreements with 26 countries. As of mid-2019, according to the statistics of the Maritime Administration, Vietnam has 281 ports with a total capacity of over 550 million tons per annum. Cargo through Vietnam's seaports are continually rising; the average growth rate of goods in the 2000-2017 period was approximately 10.4 per cent ${ }^{1}$. Seaport development contributes to promoting local and national economies. In order to achieve the above results, economic policies, as well as macroeconomic factors, play an important role in promoting the seaport industry. To better understand the relationship of macroeconomic factors and the development of seaport, this paper uses statistical data over 19 years, from

\footnotetext{
${ }^{1}$ Website of Vietnam Maritime Administration: http://www. vinamarine.gov.vn.
} 


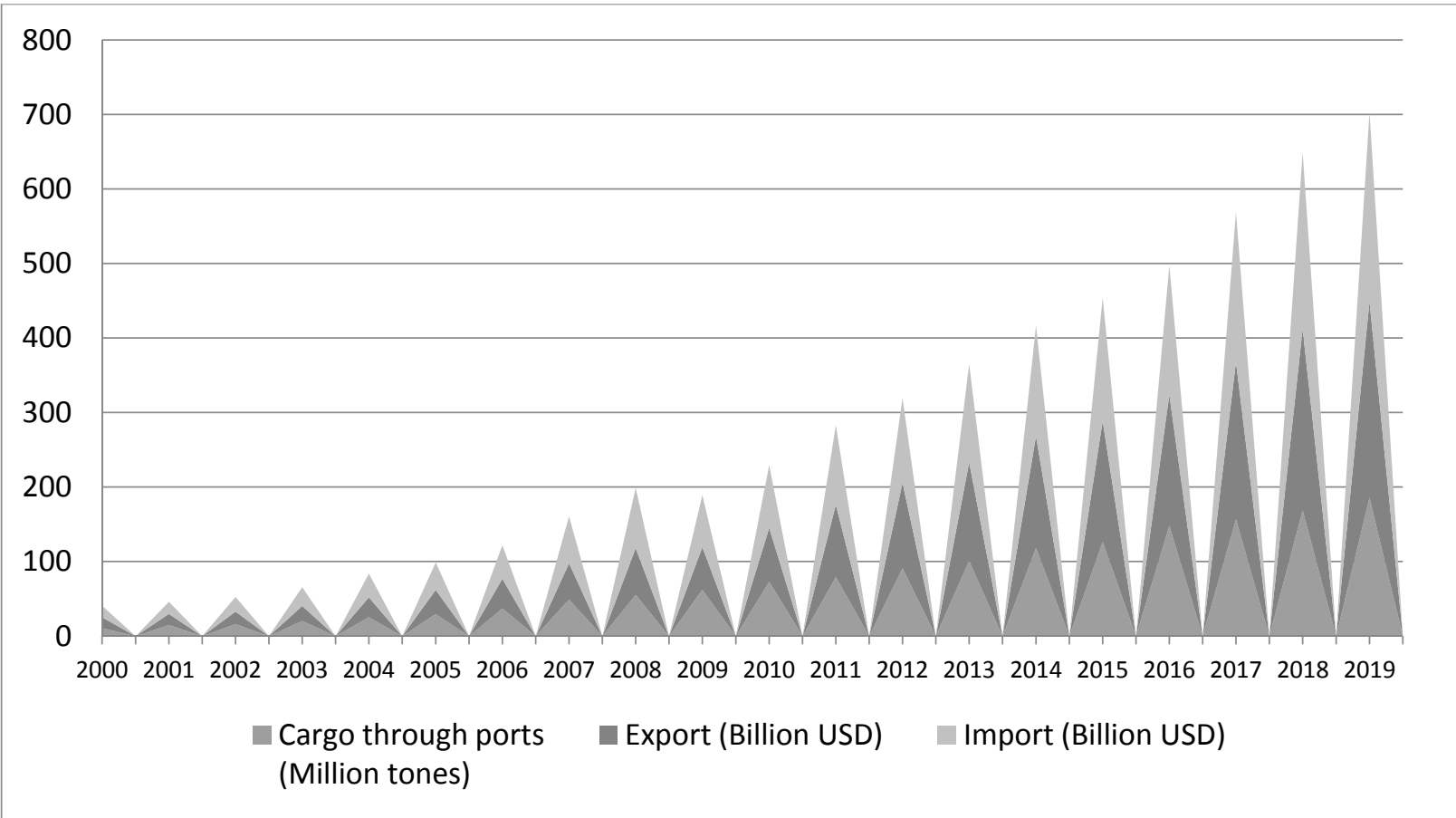

Fig. 2. Cargo through seaports and import-export value of Vietnam in the period 2000-2019

Source: Vietnam General Statistics Office and the Vietnam Maritime Administration, 2019.

2000 to 2019 , to analyse the trend and fluctuations of cargo through ports and macroeconomic factors (GDP, export-import value and industrial-agricultural value). Statistical data over a long period shows the relationship between macroeconomic variables and seaport activity. First of all, GDP has led to the development of seaport.

The graph above shows that GDP and cargo through Vietnam's seaports grew in the same direction from 2000 to 2019 . This result is consistent with previous studies in different countries. In recent years, Vietnam has been ranked in one of the countries with high and stable economic growth. The result is due to the government's flexible management of macroeconomic policies as well as the determination to improve business and investment environment to attract foreign investment and create resources for economic development in the country. The attraction of foreign investment, as well as domestic economic growth, have increased the volume of goods, which means that the demand for transport and circulation of goods has increased, thereby increasing the output of goods through ports and promote the activities of seaport enterprises. However, data shows that the growth rate of GDP seemed to be higher than that of cargo through ports. For the seaport development to respond adequately with the demand of the economy, the seaport industry needs to improve the quality of services, especially services to support shipping; developing modern fleets, large vessels and specialised vessels.

Along with economic growth, the development of import-export activities has mainly contributed to the increase in cargo through ports, as shown in the following graph.

The statistics in the period 2000-2019 show that Vietnam's export-import activities grew strongly in the same direction as the growth of goods through ports. The import-export activities directly and positively associated with increased cargo. It is understandable because Vietnam is a country that has a coastline along with the country, so maritime transportation is an advantage of Vietnam in international trade. Marine transportation allows reducing costs and creating a competitive advantage. Therefore, the development of import-export activities will increase cargo and promote the development of seaport services. Especially in 2009 , the volume of goods through seaports had the largest growth rate in the period 20002019. One of the factors that led to this result was that Vietnam became a member of WTO in 2007, which increased the total volume of 


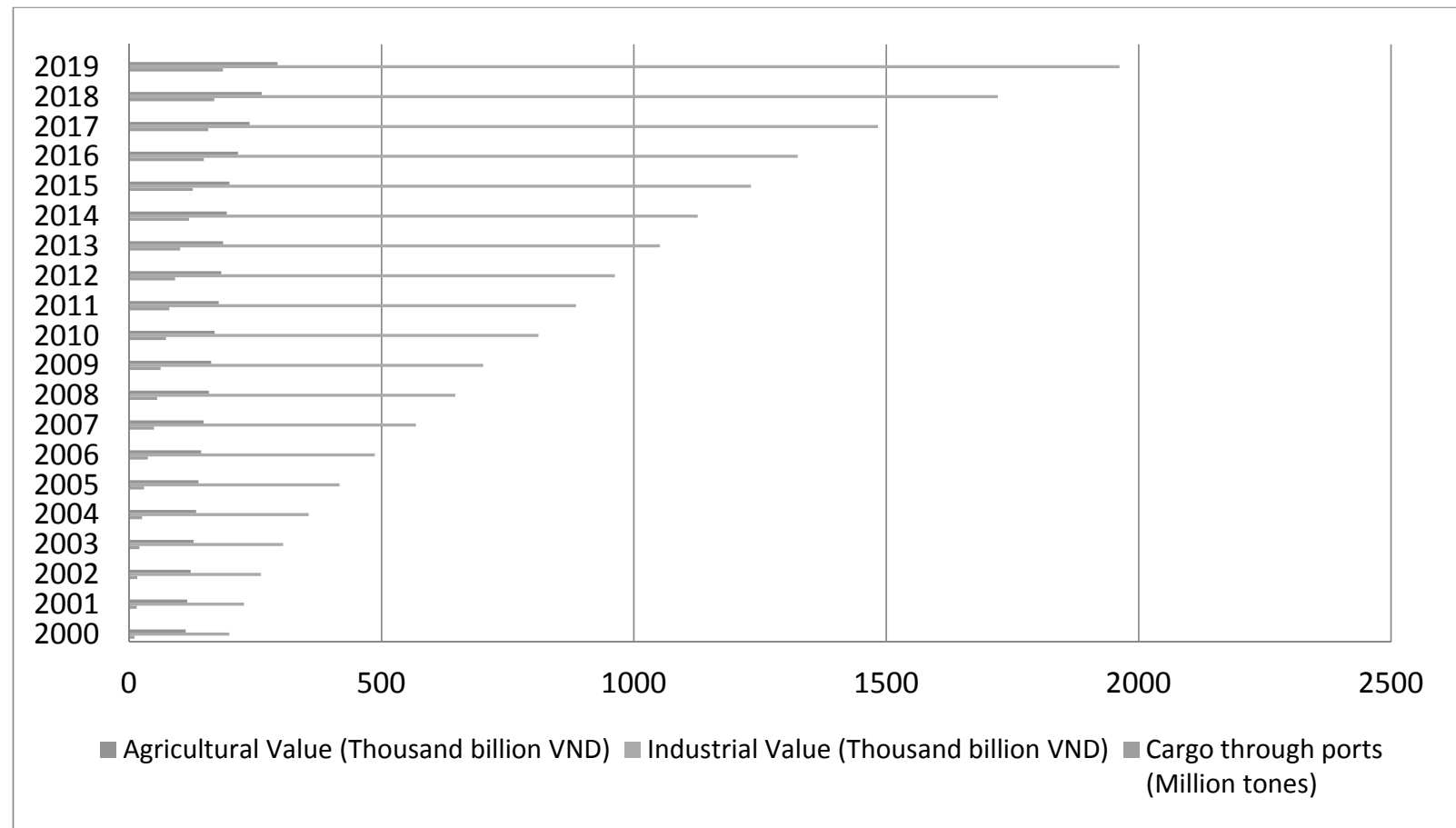

Fig. 3. Cargo through seaports and industrial \& agricultural value of Vietnam in the period 2000-2019 Source: Vietnam General Statistics Office and the Vietnam Maritime Administration, 2019.

goods exported and imported through Vietnam's seaports (Nguyen \& Ngo, 2017). Since 2014, import and export activities have grown by an average of 15 per cent. At the same time cargo through ports has also increased sharply, with an average rate of 10 per cent. It shows the positive impact of import-export activities in seaport development.

Besides promoting the development of international trade through import-export activities, the development of industry and agriculture has a definite impact on the development of seaports. For Vietnam, will the development of industry and agriculture promote the development of seaport enterprises? The growth rates of these two activities between 2000 and 2019 partly reflect this relationship.

From 2000 to 2019, Vietnam's industrialagricultural value increased continuously, in which the industrial growth value was larger than agriculture. The graph depicts a growing, steady and positive trend in industry, agriculture and cargo through ports over the years. The increase in industrial-agricultural output has increased the volume of domestically produced goods and affected the volume of goods through seaports. With the coastline along with the country, maritime transportation is not only used for import-export goods but also domestic trade. According to the statistics of the Maritime Administration, the proportion of domestic goods through ports accounted for over 20 per cent of the total volume of goods through ports. It means that the development of industry and agriculture will positively affect the volume of goods through Vietnam's ports.

Vietnam's statistics show that macroeconomic factors have a positive effect on the volume of goods through ports, namely the impact of GDP, the value of import-export and value of industry-agriculture. As the economy grows and economic integration deepens, it will expand the trade between Vietnam and the world, which will create favourable conditions for seaport development. We can say that the seaport industry of Vietnam in particular and of other countries, in general, depend significantly on the economic policies and level of the economic integration of the states. Indeed, domestic maritime transportation in $\mathrm{Vi}$ etnam only accounts for more than 20 per cent of cargo through ports; the rest comes from import-export activities. Therefore, strengthening the integration and implementation of macroeconomic policies to promote economic development, attract foreign investment, promote import-export activities are an important 
base for the development of seaport activities. Besides, Vietnam should invest in infrastructure, upgrade seaport infrastructure, improve logistics and customs services to enhance the quality of Vietnam's seaport service.

\section{Conclusion}

With the advantage of $3,260 \mathrm{~km}$ of a long coastline, many deep-water bays, near international maritime routes and the location right next to the South China Sea, Vietnam's seaport industry plays an important role in economic development and integration. However, seaports in Vietnam have been focused and developed since 2015 and became active since 2017 when Vietnam expanded economic integration (Nguyen \& Ngo, 2017). It shows that macroeconomic policies have profound impacts on seaport activities. According to statistics, the study points out the positive movement between economic growth, importexport value, industrial-agricultural value and goods through the port. Therefore, to develop the seaport industry, it is necessary to have appropriate macroeconomic policies, especially international trade policies, to accelerate the trade process to promote import-export activities. Likewise, it is the increase of industrial-agricultural value to increase the volume of goods, thereby increasing the supply-demand of goods through Vietnam's seaports system. The study highlights the relationship between macroeconomic factors and seaport development. Still, the research stops at analysing statistical data, which suggests further quantitative research to measure and evaluate the impact of each macroeconomic factor on cargo through seaports.

\section{References}

Baird, B. A. (1998). Public Infrastructure and Economic Productivity, Transportation Focused Review. Journal of Transportation Research Board, 1932, 54-60.

Bayar Caglak, S., Alkan, G., \& Aydin, G. (2011). The impact of seaport investments on regional economics and developments. International Journal of Business and Management Studies, 3(2), 333-339.

Boonadir, N., Jeevan, J. Aslamm, N. M., \& Hamid, S. A. (2012). Seaport development: A study on customer attraction to Westport, port Klang, Malaysia. Business Management Dynamics. 2(8), 08-19.

Bottasso, A., Conti, M., Ferrari, C., \& Tei, A. Ports and regional development: a spatial analysis on a panel of European regions. Transportation Research Part A: Policy and Practice. 65, 44-55.

Chang, Y-T., Shin, S-H., \& Lee, Pt-W. (2014). Economic impact of port sectors on the South African economy: An input-output analysis. Transport Policy, 35, 333-340.

Chowdhury, A., \& Erdenebileg, S. (2006). Geography against Development: A Case for Landlocked Developing Countries. United Nations, NewYork.

Dwarakish, D. S., \& Salim, A. M. (2015). Review on the role of ports in the development of a nation. Aquatic Procedia, 4, 295-301.

Jiang, N. (2010). Seaport investment and economic development in China. Dailian Marine University Press. Jouili, T. (2016). The role of a seaport in the process of economic growth. Developing Country Studies, 6(2), 64-69.

Jouili, T., \& Allouche, M. A. (2014). The impact of public investment in seaports infrastructures on economic growth: the Tunisian context. International Journal of Management Research and Development, 25, $25-33$.

Jouili, T. A., \& Allouche, M. A. (2016). Impacts of seaport investment on economic growth. Transportation Economy Preliminary Communication. DOI: 10.7307/ptt.v28i4.1933.

Jung B. M. (2011). Contribution of Ports to the Local Economies in Korea. The Asian Journal of Shipping and Logistics, 27(1), 1-30.

Goodwin, A.P. (2016). The economic value of shipping and maritime activity in Europe. Oxford Economics. Retrieved from https://www.oecd.org/sti/ind/Session\%201_c\%20-\%20Andrew\%20Goodwin\%20-\%20Presentation\%20for\%20Website.pdf

Nguyen, T.K.C., \& Ngo, T.Q. (2017). Seaport industry report. FPT Securities.

Nguyen, X. P, \& Nguyen, P. Q. P. (2018). Strategies for maritime development: A case in Vietnam. European Journal of Engineering Research and Science, 3(12), 14-19. DOI: http://dx.doi.org/10.24018/ejers.2018.3.12.986

Norcliffe, G. B. (1981). Industrial Change in Old Port Areas. The Case of the Port of Toronto. Cahiers de géographie du Québec, 25(65), 237-253. DOI: 10.7202/021515ar. 
Oxford Economics. (2013). The Economic Impact of the UK Maritime Services Sectors: Ports, A Report for Maritime UK.

Park, J. S., \& Seo, Y-J. (2016). The impacts of seaports on the regional economies in South Korea: Panel evidence from the augmented Solow model. Logistics and Transportation Review, 85, 107-119.

Report Buyer. (2019). Vietnam logistics industry comprehensive report Q4/2019. Report ID: 5843680.

Tukan, M., Achmadi, T., \& Widjaja, S. (2015). International Journal of Technology, 3, 422-431.

Vietnam Maritime Administration Statistics: http://www.vinamarine.gov.vn.

\section{Макроэкономика и развитие морского порта. Пример Вьетнама}

Тхи Хонг Ван Фам, Тхи Май Тхон До

Вьетнамский морской университет, Хайфон, Вьетнам

Аннотация. Портовая промышленность играет важную роль в развитии местной и национальной экономики Вьетнама. Развитие морской отрасли создает конкурентные преимущества, способствует развитию международной торговли и ускоряет процесс интеграции государств, особенно в развивающихся странах. Экономическое развитие также является одним из важнейших факторов развития вьетнамских морских портов. В первую очередь развитие импортно-экспортной деятельности, которое напрямую влияет на масштабы их деятельности. В настоящем исследовании на основе данных за 2019-2000 гг. анализируется взаимосвязь между экономическим ростом, экспортно-импортными операциями, промышленностью, сельским хозяйством и объемом грузооборота через порты Вьетнама, обладающего протяженной береговой линией и входящего в «четверку» ведущих судоходных стран в регионе АCEAH.

Ключевые слова: портовая промышленность; грузы через порты; ВВП; импорт-экспорт; промышленность и сельское хозяйство 